\title{
Simultaneous Determination of Firm Leverage and Private Benefits of Control in French Firms
}

\author{
Raoudha DJEBALI \\ High Institute of Management of Tunis \\ University of Tunis 1 , Tunisia \\ E-mail: djebaliraoudha@yahoo.fr \\ Amel BELANES (Corresponding author) \\ High Institute of Management of Tunis \\ University of Tunis 1 , Tunisia
}

Tel: 216-98-979-275 E-mail: amel_bns@yahoo.fr

\author{
Abdelwahed OMRI \\ High Institute of Management of Tunis \\ University of Tunis 1, Tunisia \\ E-mail: abomri@yahoo.fr
}

Received: September 26, 2011

Accepted: October 25, 2011

Published: January 1, 2012

doi:10.5539/ijef.v4n1p177

URL: http://dx.doi.org/10.5539/ijef.v4n1p177

\begin{abstract}
This study investigates whether the firm leverage breed private benefits of control in France ; or that is private benefits of control that drive the firm financing policy. Most French firms are family-owned and highly concentrated and hence the controlling power of block-shareholders. Private benefits of control are particularly high in France. They can be extracted by both large shareholders through related-party transactions and managers via their compensation. If debt effectively curbs the private benefits of control, the controlling party is also given incentives to increase debt. Using a sample of 110 listed firms during 2002-2006, our modeling puts in evidence a simultaneous relationship between firm leverage and the private benefits of control. Empirical results reveal that debt is positively associated with related party-transactions but negatively related with excessive managerial compensation. The controlling shareholders are tempted to increase the firm leverage so as to increase their own private benefits. The manager however wants to maintain his private benefits already siphoned off and aims therefore at reducing the firm debt.
\end{abstract}

Keywords: Private benefits of control, Firm leverage, Related party transactions, Excessive managerial compensation, Stock ownership

JEL Classification: G21; G28; G32; G34

\section{Introduction}

Since Modigliani and Miller's seminal works $(1958,1963)$, capital structure has been an issue of great interest in the finance literature. Many researchers have devoted much effort to understand firms' policy choices, namely leverage policy. The value-maximizing debt level is recognized to be the output of a trade-off between tax benefits and costs of financial distress (Kraus and Litzenberger, 1973). However, models based upon such claims generally can neither predict the observed leverage ratios nor explain the cross-sectional variations in capital structures. One potential explanation for these limitations is that these models have overlooked some determinants of debt policy in particular the impact of agency conflicts on firms' financing decisions. There is a substantial body of research in financial economics, since Jensen and Meckling (1976), which has analyzed the impact of agency conflicts on firm's policy choices (Bebchuk, 1994; Modigliani and Perotti, 1997; Shleifer and Vishny, 1997; La Porta et al., 1998; Filatotchev et al., 2001). An agency conflict that has received a lot of attention in the corporate finance literature is 
which between bondholders and shareholders. Another agency cost that becomes recently at the core of the theory is which that arises from the conflicts among shareholders, namely controlling and minority shareholders. Both agency costs can influence the investment and financing decisions.

For instance, debt has been argued to provide a hard mechanism of control that might mitigate agency conflicts at least for four reasons. First of all, managers are compelled to do their best so as to enhance the firm performance and thereby afford the debt and interest payments (Grossman et Hart, 1982; Harris et Raviv, 1990; Stulz, 1990). Secondly, firm leverage is expected to reduce free cash flow that would be spent either for unprofitable investments or in empire building (Jensen, 1986). Third, it can be associated with the provision of active monitoring through bank-corporate relationships (Myers and Majluf, 1984). This can be further re-enforced with the help of auditing and business consulting roles of the fixed-claim holders (Myers and Majluf, 1984; Jensen, 1986). Fourth, firms have to resort to external finance more frequently which in turn would signal to external capital markets the firms' growth opportunities and hence facilitates the external monitoring of firms (Ross, 1977).

Firm leverage is then recognized to be a disciplining mechanism that lessens the expropriation problems. Private benefits of control are hence expected to be reduced with the increase of the firm leverage. These benefits are defined as advantages that are not shared by the other shareholders, but exclusively siphoned off by the controlling party, to his own interest (Grossman and Hart, 1980). They are generated from the separation of the residual claim right and residual right of control attributed to the controlling holder (Weifeng et al., 2008). The residual claim right consists of the cash flow right in proportion to the owned shares, that is the return on investment. The residual right of control is the voting right that has the controlling holder. The inconsistency of both rights leads to private benefits of control. But is debt effective as in reducing agency costs as in curtailing the private benefits of control?

Based upon the predictions of the trade-off and the pecking order theories, the debt ratio reflects the cumulative requirement for external financing and firms would rather prefer issue debt to equity. In the trade-off theory, optimal capital structure is reached when the tax advantage to borrowing is balanced by costs of financial distress (Kraus and Litzenberger, 1973). In the pecking order theory, firms prefer internal to external funds; and debt to equity if external funds are needed (Myers and Majluf, 1984). Consistent with the rent-protection theory of Bebchuk (1994; 1999), when private benefits are huge enough, the controlling party increase the firm leverage so as to escape any equity issue and retain the control.

Beyond that, agency and signaling theory suggest that a firm's debt and private benefits of control are related not only to similar firm-specific attributes, but directly to each other. Both of them are ultimately related and determined by the insider ownership. In the light of the direct and indirect relationships between private benefits and firm leverage, the motivation for simultaneous study is clear. The main bulk of studies have largely been qualitative, neglecting the magnitude of their effects and focusing only on directional effects. Estimation within a system helps to avoid any ambiguous attribution of causality that actually stems from spurious correlations. This study therefore attempts to provide more insights into the literature by investigating a simultaneous relationship between private benefits and capital structure.

This research is carried out in France. We choose France for at least two reasons. First, most of the previous research has focused on large, publicly traded corporations with diffused ownership within the framework of the conventional US/UK model of corporate control. Second, France provides a typical example of a civil law country in which the stock ownership is often concentrated, the legal protection is weak and consequently the expropriation of private benefits is particularly relevant. In fact, most French listed firms are family owned and the level of ownership concentration is significantly high (Faccio and Lang, 2002). Block shareholders manage the firm either directly or through delegated managers. That implies in turn that French firms exhibit a different type of agency problems. Expropriation problems occur not only between managers and shareholders but also between the large controlling shareholders and minority shareholders (Boubaker and Labégorre, 2008). Besides, French judicial environment is inefficient in protecting minority shareholders due to its weak legal protection rules and to its ineffective law enforcement system (La Porta et al., 1999). Therefore, the level of expropriation is expected to be particularly significant (Johnson et al., 2000). The private benefits of control are even far higher in France than in other developed countries and often exceed $28 \%$ of the firms' values (Nenova 2003). But above all, most of private benefits are non-pecuniary (Le Maux, 2004; Roosenboom and Schramade, 2006) and hence difficult to estimate.

The contributions of this paper are three fold. First, it is the first paper, to the best of our knowledge, which considers the simultaneous relationship between private benefits and firm leverage. Most studies have been limited by an implicit assumption that debt can limit private benefits of control. Empirical studies focus little attention on the impact of private benefits of control on debt policy. Second, it is the first study that deals with wealth 
expropriation through related-party transactions in the French market. Third, it offers another different proxy for managerial private benefits of control; that is excessive managerial compensation.

The remainder of the paper proceeds as follows. Section 2 covers the relevant literature on relationship between the capital structure and the private benefits of control. Section 3 describes the data and outlines the research design. Section 4 discusses the empirical results. A brief conclusion follows with implications of findings and suggestions for future research.

\section{Literature Review}

Despite a great deal of prior research on private benefits of control, most previous research has focused on equity financing and has not considered whether the magnitude of private benefits of control varies with the firm leverage. But above all, there is a wide recognition that debt can deter the expropriation of private benefits of control rather than the level of the private benefits can influence the firm leverage. Empirical studies focus little if any attention on the potential causal relationship between private benefits and debt policy.

\subsection{A survey of Private Benefits of Control}

Private benefits are defined as profits and advantages that are not shared with other shareholders, but exclusively siphoned off by the controlling party, to his own interest (Grossman and Hart, 1980). There is a wide range of wealth expropriation and both large shareholders and managers do enjoy private benefits of control. Block-shareholders have not only the motive to maximize corporate value of the controlled firms but also have an incentive to use their voting rights to consume corporate resources for their own interest, namely through tunneling. Tunneling includes activities ranging from outright theft to self-dealing transactions, namely transferring or selling assets or products at higher than market price to a block-holder-controlled firm, or buying at a low price from the firm. Block-shareholders can also obtain loans on preferential terms or even dilute the interests of minority shareholders by acquiring additional shares at a preferential price (Johnson et al., 2000; Cheung et al., 2009).

Managers would also reap private benefits at the expense of shareholders (Bebchuk, 1999; Dyck and Zingales, 2004; Hwang and $\mathrm{Hu}, 2009)$. Although there is little evidence that managers use their own voting power to extract higher salaries, there are various ways through which they can expropriate the created wealth. Top executives generally enjoy larger perquisites and exorbitant compensation packages (Jensen and Meckling, 1976). They can even abuse their control rights to engage in projects that benefit themselves rather than investors (Jensen, 1986). Furthermore, their resistance to takeovers aims essentially to preserve their private benefits of control (Field and Karpoff, 2002).

Generally, private benefits can be divided into two categories: pecuniary and non-pecuniary. Prior studies focus on pecuniary private benefits of control that are visible and can be transferred to an outside acquirer. However, non-pecuniary or psychic private benefits may be equally important although they are inherently difficult to measure (Jensen and Meckling, 1976). Excess salaries, perks and larges bonuses as well as charitable contributions are some examples of pecuniary benefits. The excess payments of holding company and the underestimated or overestimated internal sale prices in firms groups also reflect the pecuniary private benefits of control. The non-pecuniary benefits include the prestige and social status, the ability to employ family members and to appoint them on the board (Demsetz and Lehn, 1985; Ehrhardt and Nowak, 2003). Psychic benefits consist also in privileges of control, the power to make decisions on business strategy, the disciplinary level of the employees, the independence from superiors and even personal relationships (Holderness, 2003; Weifeng et al., 2008). The amenities that apparently come from controlling corporations like professional sports teams and newspapers are non pecuniary private benefits as well.

\subsection{Prior Evidence on the Relationship between Private Benefits and Debt Policy}

Consistent with the Jensen-Meckling incentive effect, a high level of concentration may provide an incentive to the dominant shareholder to decrease private benefits of control (Claessens et al., 1999; La Porta et al., 2000; Filatotchev et al., 2001). Larger stock ownership would breed a greater incentive to increase the firm value and constrain the consumption of perquisites. With the increase of the firm leverage, block-shareholders may not meet the debt payments and are threatened by bankruptcy. Dominant shareholders do not want to put at stake the firm and squander their wealth accumulated through decades. Therefore, private benefits are expected to decrease so as to comply with the debt obligation payments. Similarly, according to the agency and free cash-flow theories and corporate governance literature, private benefits of control expropriated by managers are also assumed to be curtailed with the increase of the firm leverage. In fact, the pressure from periodic cash outflows incites managers to avoid high leverage and improve their decision making and avoid bad projects. Besides, a manager of a highly levered firm may suffer the private costs of control that requires a higher level of commitment to maintain financial solvency. For instance, managers who do not face active monitoring or firm-value-linked incentive schemes tend to 
decrease leverage (Mehran, 1992; Berger et al., 1997). Managerial entrenchment is then reduced as well as the private benefits of control expropriated when the firm is indebted.

However, the governance role of debt may not be as straightforward as previous research suggests. The opportunistic behavior of controlling owners is not restricted by debt-holders, as long as the firm does not default on its outstanding debt (Faccio et al., 2010). In fact, when private benefits of control are large enough, block-shareholders would rather increase the firm leverage than issue equity. Building on the rent-protection framework developed by Bebchuck $(1994 ; 1999)$, when private benefits are great, control is too valuable for entrenched concentrated owners. They would prefer to bear more agency costs than give up their control. Surrendering control would attract attempts to assemble a controlling stake by rivals seeking to capture the private benefits. In fact, in an environment of poor legal enforcement, the value of control rights is generally greater than that which controlling shareholders could hope to gain by selling out shares to equity investors (Modigliani and Perotti, 1997).

This is in line with the predictions of both the pecking order theory and the trade-off theory. The trade-off theory states that firms balance tax saving benefits of debt against deadweight bankruptcy costs (Kraus and Litzenberger, 1973). Firms should choose how much debt finance and how much equity finance to use by balancing the costs and benefits so as to determine an optimal capital structure. Often agency costs are also included in the balance. Issuing equity means moving away from that optimum and should therefore be interpreted as bad news. Therefore, companies facing higher corporate tax rates are punished more severely by their investors when they announce an equity issue. The pecking order theory points out that, due to adverse selection, firms prefer first to finance investment with retained earnings, then, when they need outside funding, they prefer to issue debt instead of equity (Myers and Majluf, 1984). Concentrated shareholders are then reluctant to use private equity and are tempted instead to increase the firm leverage despite the additional agency costs (Mueller, 2008). They are willing to pay high interest rates for additional debt to keep control. They often forego profitable opportunities when they can not be financed solely by debt and need extra funding. They fair the loss of control.

Besides, the controlling parties might collude with banks and other providers of intermediated finance in extracting the control premium. As long as fixed-claim holders provide firms with ready access to funds for expansion, private benefits accrue for both suppliers of credit and controlling shareholders (Harris and Raviv, 1990). Private benefits will be enlarged for both sides with the raise of debt. Both sides will collude concerning preferences for profit retention over distributing dividends (Baums, 1993). Banks can even neither interfere nor monitor the firm-level strategic and operating decisions (Holland, 1994). It should be noted here that block-shareholders are often tempted to abuse debt and use it inefficiently (Filatotchev and Miekiewicz, 2006). For instance, they can sponsor their affiliated financial companies or other firms under their control. They can also extract some of new debts before the completion of the investment project. As long as they can collude with fixed-claim holders in extracting the control premium, they can afford external funds in smoothing conditions and low rates of interests.

However, when the increase of the firm leverage would reduce the marginal benefits of expropriation, the controlling party would avoid additional debt (Claessens et al., 1999; Bennedsen and Wolfenzon, 2000). For instance, entrenched managers who expect a loss of private benefits accompanied by disciplinary debt obligations may favor low debt. In this vein, when the manager has a long tenure or performance-insensitive compensation, or has to comply with a controlling party, he attempts to decrease the firm leverage (Mehran, 1992; Berger et al., 1997).

\section{Data and research design}

In this section, we present first the research method and data collection. We define second the different estimates used of the private benefits of control, the firm leverage, the stock ownership as well as the other firm characteristics. We finally outline the regressions specifications.

\subsection{Sample Selection and Data}

Our sample includes the French listed firms belonging to the SBF250 (Société des Bourses Françaises 250 index). SBF250 is the French stock market index representing all sectors of the French economy. It includes the first 250 listed French firms belonging to the index CAC All Shares. The latter consists of all the listed firms of the Stock Exchange of Paris. SBF250 contains all the component stocks of the CAC40, CAC Next 20, CAC Mid 100 and CAC Small 90. We exclude all regulated firms, namely financial corporations such as banks and insurance companies. We also eliminate firms with missing data relative to the stock ownership, CEO compensation, related party transactions and financial statement. Data on the ownership structure, CEO compensation, related party 
transactions and financial accounting have all been manually collected either from the reference document available on the website of the AMF (Autorités des Marchés Financiers) or the annual reports. Our panel data set includes 110 firms for the period spreading from 2002 to 2006.

\subsection{Variables Estimates}

Three sets of variables are used in our study: those to proxy the private benefits of control, the estimates of the firm leverage and stockownership concentration and the firm characteristics variables.

\subsubsection{Measuring Private Benefits of Control}

Many studies have attempted to measure private benefits of control through indirect proxies of the degree of expropriation, namely the legal system (Djankov et al., 2008; Johnson et al., 2000; La Porta et al., 2000), the deviation of cash flow from control rights through the ratio of control rights on stockownership (Lease et al., 1983; Zingales, 1994). The deviation of cash flow from control rights is measured by the ratio of control rights to stockownership. Other studies have used direct proxies based upon the pricing of stock blocks trades (Barclay and Holderness, 1989; Dyck and Zingales, 2004), the control premium, that is the spread between the prices of two classes of stock, that have one or more control rights (Nenova, 2003; Masulis et al., 2009), the salaries (Ehrhardt and Nowak, 2003), the abnormal related-party sales (Conover and Nichols, 2000) and the amount of connected transactions (Tai et al., 2007; Berkman et al., 2009; Cheung et al., 2009).

In our study, we estimate private benefits that accrue to both managers and block-shareholders. We use direct proxies, namely the amount of related party transactions and excessive managerial compensation. RPT is the proxy of the related party transactions. It is measured by the neperian logarithm of the sum $(1+$ the amount of related party transactions). Excessive salaries are measured through the variable Exc_comp. To count the CEO excessive compensation, we first measure the spread between the management wage and the sector-based average; we calculate then the neperian logarithm of this spread. It should be mentioned here that there is no empirical research that has estimated private benefits of control in French firms through excessive salaries and one research that has used related-party transactions (Le Maux, 2004). That is thanks to recent laws and especially the NRE 2001, that French managers are obliged to disclose the amounts of related party transactions and their compensations in their annual reports.

\subsubsection{Debt and Ownership Variables}

Following Rajan and Zingales (1995), financial leverage is defined by the ratio of debt (both short term and long term) to total assets. The variable used is LEV. It is calculated in terms of book value, rather than in terms of market value to avoid problems of multi-collinearity with the proxy for growth opportunities (Titman and Wessels, 1988).

The effect of ownership concentration on firm leverage is far from obvious (Rajan and Zingales, 1995). Therefore, it is worth including the stock ownership concentration when studying the relationship between the private benefits and firm leverage. The presence of controlling shareholders may decrease the level of debt especially when they are directors or they hold undiversified portfolios. However when some of these large shareholders are banks, bank debt might become the best external source.

The ownership structure is revealed through the stockownership concentration. Only one variable, CONC, is used. It is measured by the percentage of common shares owned by the three largest shareholders. This proxy was already used and justified in previous studies (Brailsford et al., 2002; Dyck and Zingales, 2004; La Porta et al., 1998).

\subsubsection{Firms Characteristics Estimates}

Four additional variables dealing with the firms characteristics are incorporated, namely the firm size (SIZE), profitability (ROA), growth opportunities (Growth), and asset tangibility (TANG). These variables may exert a significant impact on both the firm leverage and the amount of private benefits of control

The firm size is measured by the neperian logarithm of total assets (SIZE). The logarithmic transformation is used to eliminate the effect size that would mainly affect small companies. Several studies have found ambiguous results on the relationship between debt and firm size. The size of the company can estimate the probability of bankruptcy, which is high for small firms (Rajan and Zingales, 1995). Large companies are more transparent, suffer less from asymmetric information and have more access to capital markets and can borrow at better terms. Thus, the size of the company positively affects the level of debt. However, information asymmetry is less severe in large firms than small firms. Outside investors may have easier access to company information. This allows larger companies to directly raise equity capital markets, and therefore larger firms are expected to use less debt to finance their projects.

We control for the growth opportunities using market-to-book-ratio (Growth). The relationship between debt ratio and market-to-book is expected to be negative in French firms like their homologue U.S., German, British and 
Canadian firms (Rajan and Zingales, 1995). Indeed, companies with significant investment opportunities are more profitable and, therefore, they could rely more on internal funds rather than debt. Firms with higher growth opportunities should be less levered, because they are subject to higher costs of financial distress (Bradley et al., 1984; Fama and French, 1992; Maksimovic and Titman, 1991). This relationship is already predicted by the Peking-order- theory of Myers and Majluf (1984).

The firm profitability is proxied by the return on assets (ROA). The pecking order theory, proposed by Myers and Majluf (1984) suggests a negative relationship between profitability and debt. Indeed, the most successful firms use less debt because they have sufficient internal funds to finance their investments. Several empirical studies have found a negative relationship between profitability and debt (Friend and Lang, 1988; Jensen et al., 1992). The profitability of the company's assets is measured by the ratio of operating income to total assets.

Finally, the asset tangibility is estimated by the variable (TANG) which is the ratio of tangible assets divided by total assets. Tangible assets have a positive impact on leverage of firm because they are less prone to asymmetric information (Rajan and Zingales, 1995). They offer guarantees to creditors and thus agency costs of debt. Without these guarantees, lenders are likely to impose much tougher loan conditions to offset the risk of asset substitution, which incites the company to resort to the equity issue as a cheaper source of financing.

\subsection{Regressions Specifications}

Our analysis aims at revealing the determinants of both policies of private benefits of control and firm leverage. Previous studies have invoked information costs and agency problems to explain each policy independently. However, both of them are determined conjointly and are related to the firm's characteristics. A simultaneous equations framework is then the natural tool to identify the effects of these two interdependent decisions.

To investigate the relation between private benefits of control and leverage, we estimate successively three kinds of models. We first investigate the impact of debt on the private benefits of control, then the impact of the latter on the former and finally the simultaneous relationship between them.

First of all, we consider that the private benefits of control are a function of debt ratio (Model 1). Secondly, we test the modeling where the dependent and independent variables are respectively leverage and private benefits of control (Model 2). Finally, we carry out a two-stage least squares analysis in order to test the endogeneity of both estimates (Model 3). For all these models, two proxies of private benefits are used: related party transactions (RPT) and CEO excessive compensation (Exc_comp).

Model 1: Private benefits of control $=f$ (Leverage, Ownership structure, Control Variables)

Model 2: Leverage $=f$ (Private benefits of control, Ownership structure, Control Variables)

Model 3: $\left\{\begin{array}{l}\text { Private benefits of control }=\mathrm{f} \text { (Leverage, Ownership structure, Control Variables) } \\ \text { Leverage }=\mathrm{f} \text { (Private benefits of control, Ownership structure, Control Variables) }\end{array}\right.$

To estimate models 1 and 2, panel data approach is considered. This approach is worth applied compared to cross-sectional approach. This allows more informative data, more variability, less colinearity among the variables, more degrees of freedom and more efficiency (Baltagi, 1995). The heterogeneity of firms is captured by including firm-specific effects. The Hausman test is then used to verify whether theses specific effects are random or fixed. However, the presence of either the auto-correlation or the heteroscedasticity may lead to biased results. Such models should be enhanced by including generalized least squares.

To estimate model 3, we run a two-stage least squares (2SLS) analysis of panel data. 2SLS is a statistical procedure that is used to correct for simultaneity bias and errors in variables. When applied to certain kinds of models, however, 2SLS is itself susceptible to bias as a result of random and nonrandom measurement error in the data. Besides, panel data offer decided advantages over cross sectional analyses in testing for potential reciprocal simultaneous effects between variables. Therefore, we use the system 2SLS estimator for the linear panel data model as suggested by Wooldridge (2006).

\section{Empirical Results}

This section reports the summary statistics of the variables used in the study and covers the empirical evidence regarding to the relationship between private benefits of control and firm leverage.

\subsection{Descriptive Statistics and Univariate Analysis}

Table 1 recapitulates the descriptive statistics of the estimates of the firm leverage, the CEO excessive compensation, the related-party transactions as well as the firms characteristics.

Insert Table 1 Here 
Table 1 puts in evidence that French firms are highly levered and the stock ownership is locked in the hands of the three largest shareholders. The total debt of most firms represents 0.54 of their total assets. The average percentage of common shares owned by the three largest shareholders of French companies is about $45.3 \%$ (median $46.6 \%$ ) and varies from $3.3 \%$ to $99.9 \%$. Thus, the three largest shareholders hold on average the half of the capital; which justifies the proxy of stock ownership concentration through the shareholding of the three largest shareholders in our study. Before estimating models, we should analyze the correlation matrix of independent variables. Table 2 provides the correlation coefficients of variables used in the analysis. Almost all variables are significantly correlated with debt ratio. Such result provides the univariate support for their relevance.

The results of correlation test in Table 2 show a significant positive relationship between the related party transactions and the firm leverage. Such results reveal that the firm leverage increases with the level of private benefits of control, as stipulated by the study of Mueller (2008). This study assumes that firms with high levels of private benefits of control are likely to have more debt. However, the correlation between the CEO excessive compensation and debt ratio is significantly negative in contrast to which between related-party transactions and leverage. This suggests that these benefits of control measures do not convey the same concerns. Table 1 points as well a negative correlation between leverage and profitability as predicted as more profitable firms are expected to have lower debt.

Insert Table 2 Here

\subsection{Evidence of the Impact of Firm Leverage on Private Benefits of Control}

Based on the theoretical arguments of Bebchuk (1999) and findings from some empirical studies (Dyck and Zingales, 2004), we identify the factors explaining the level of private benefits of control, namely firm leverage, ownership concentration, dual-class-share firms, cross-listed firms, diversification, size, profitability, growth opportunities and assets tangibility. Table 3 highlights the empirical results related to the impact of debt on private benefits of control.

Insert Table 3 Here

Table 3 puts in evidence that the influence of the firm leverage varies with the identity of the beneficiary of private benefits. The results are consistent with the univariate analysis and show that firm leverage increases the volume of related party transactions but decrease the CEO excessive compensation. Thus, the governance roles of debt may not be as straight forward as previous research suggests, in particular when dominant shareholders have enough power to extract private benefits of control and influence firm financing decisions. This expropriation occurs even when the firm is indebted and relies on intermediated forms of funding (Fitatotchev and Mickiewicz, 2006). Debt has no longer a disciplining governance role. It can instead increase the private benefits of control of the controlling shareholders.

Besides, it seems that the size of private benefits of control increases with the ownership concentration. The results are consistent with the hypothesis that the private benefits of control are larger if the controlling shareholders hold the main large proportion of the shares (Barclay and Holderness, 1989; Le Maux, 2004; Zhang et al., 2008). Table 3 also points out that the ability of the controlling shareholder to extract private benefits is lower whenever the firm is cross-listed in the United States (Doidge et al., 2009). In the same vein, our study shows that dual class firms have an average benefit of control higher than other firms. Thus, the ability of the largest shareholders to extract private benefits is increased in the firms that issues different class of shares (Masulis et al., 2009). Finally, we find that firms that diversify their activities have a higher level of private benefits of control than firms that have a unique activity (Dahya et al., 2008).

\subsection{Evidence of the Impact of Private Benefits of Control on Firm Leverage}

Table 4 recapitulates the empirical results of the impact of private benefits, namely related party transactions and the CEO excessive compensation, on firm leverage. We first investigate the impact of private benefits on the firm leverage without taking into account the stockownership concentration (Columns 1 and 3); and then we add it in a non-linear relationship (Columns 2 and 4). Columns 1 and 2 exhibit the impact of related party transaction on the firm leverage while columns 3 and 4 sum up the impact of the CEO excessive compensation on debt.

The results are consistent with the univariate analysis and show that firm leverage increases with the related-party transactions but decreases with the CEO excessive compensation. The higher private benefits accumulated through related party transactions are, the more debt firm uses. In contrast, when private benefits are accrued through CEO excessive remuneration, the firm leverage is less. In fact, controlling shareholders might lose their control in an equity issue. They thus resort to bank debts to finance their investments (Bebchuck, 1994; 1999; Faccio et al., 2010; Mueller, 2008). 
Besides, Table 4 puts in evidence a non linear relationship between firm leverage and stock ownership concentration; which corroborate those of Claessens et al. (2002) who found that the relationship between ownership structure and debt changes with the level of ownership of controlling shareholders. At first, debt increases with the ownership of three largest shareholders to a level of ownership of $71.77 \%$. Beyond this threshold, the major shareholders tend to decrease debt in order to limit the possibilities of financial hardship and the loss of their benefits of control (Kang and Kim, 2006). At lower levels of ownership of controlling shareholders, debt, unlike equity can limit the dilution of their voting power. Debt is used by controlling shareholders to protect themselves against takeovers (Harris and Raviv, 1988; Stulz, 1988). It can also help the expropriation of minority shareholders by allowing controlling shareholders to dominate more resources without diluting their share of control (Faccio et al,. 2010). However, at high levels of ownership of the controlling shareholders, the latter reduce the level of debt because they fear bankruptcy. They are more risk averse than other shareholders because their investment is not diversified (Friend and Lang, 1988).

\section{Insert Table 4 Here}

Table 4 finally shows that large firms have easier more access to external funds and hence their high leverage; which is consistent with the findings of Rajan and Zingales (1995) and Brailsford et al. (2002). However, the level of debt is lower among the best performing firms. This result corroborates those of Friend and Lang (1988) and Jensen et al. (1992). The most successful companies use less debt because they have sufficient internal funds to finance their investments. Empirical results show as well that tangible assets are used as collateral for the debt (Rajan and Zingales, 1995).

\subsection{Evidence of the Simultaneous Relationship between Private Benefits and Firm Leverage}

The main objective of this paper is to emphasize the simultaneous 1 relationship between private benefits of control and firm leverage. Table 5 summarizes the empirical results of simultaneous equations framework in which private benefits of control and debt are treated as endogenous variables.

\section{Insert Table 5 Here}

The first regression equation considers the private of control as a function of firm leverage. The second equation considers the private benefits of control as a dependent variable while the debt ratio is the independent variable. The variables such as firm size, assets tangibility, growth opportunities and return on assets are introduced to capture the other determinants of capital structure and private benefits of control (Rajan and Zingales, 1995). As we consider two estimates of private benefits of control, namely related party transactions and CEO excessive compensation, we have to estimate two systems of simultaneous equations. Columns 1 and 2 correspond to the first system where private benefits are estimated through related party transactions. Columns 3 and 4 are related to the second system where the proxy of the private benefits is the excessive managerial compensation.

That is not only the leverage policy that influences the level of the private benefits of control; but also the latter does interfere when the controlling holder decides the debt level of the firm. This simultaneous relationship is in line with both the rent-protection theory and the agency theory. However, it does matter to whom accrue the private benefits: the controlling manager or the controlling shareholder. The volume of the related party transactions and the firm leverage significantly and positively influence each other while the excessive managerial compensation and the debt level significantly and negatively influence each other. These two sides of the controlling party do not consider the financing policy with the same perspective. These results are already found and explained in previous sections.

\subsection{Robustness Tests}

In this section, we check the robustness of our findings by performing several sensitivity analyses. Robustness tests are three-fold. We test whether the presence of widely held firms, the presence of family firms and the implication of the controlling shareholder in the management do alter the simultaneous relationship between private benefits and firm leverage. These tests are carried out for both measures of private benefits of control, namely the related party transactions and the excessive managerial compensation. However, only the results related to first proxy are reported. In fact, those of the second proxy become non significant due to the small size of the sub-samples. Table 6 recapitulates the results of these robustness tests.

First, we re-run the regressions after excluding widely held firms. Are our results robust to the exclusion of widely held firms? To have incentives to expropriate, the controlling owner should maintain at least $10 \%$ of the control rights, the most commonly used threshold in the literature. We re-estimate regressions after removing widely held firms. The results still remain the same (Table 6, (1)). It should be noted here that $70.5 \%$ of the sample are not widely held firms.

Second, are results driven by the over-representation of family firms? Our sample is dominated by family firms for 
above $63.7 \%$. This suggests the possibility that our findings are driven by this category. We divide our sample into two sub-samples: family firms and non-family firms. We carry out the same regression models on both sub-samples. The results still wholly remain the same for family firms. Changes for non-family firms either lose a little bit of their significance or become not significant. This is mainly due to the small sample size. (Table 6, (2) and (3)).

Insert Table 6 Here

Third, will results change whether controlling shareholder is implicated or not in firms management? In our sample, the controlling shareholder of around $65.3 \%$ of firms is involved in management. The results do not change for these firms (Table 6, (4)) and they are not significant for firms whose controlling shareholder is not involved in management (Table 6, (5)).

\section{Conclusion}

This study investigates whether the firm leverage breed private benefits of control in France; or that is private benefits of control that drive the firm financing policy. Using a sample of 110 listed firms on French stock exchange during 2002-2006, our results add new insights to the existing private benefits literature in a developed country. We take advantage of a unique opportunity to derive our measure of private benefits of control through two proxies: related-party transactions and excessive managerial compensation. Such estimates are direct proxies for private benefits of control that accrue to both managers and controlling shareholders.

The empirical findings of this study suggest a significantly positive relationship between related-party-transactions and firm leverage; and a negative relationship between CEO excessive compensation and debt ratio. Thus, the nature and the sense of the relationship between private benefits of control and financing policy vary whether the beneficiary of such benefits is the controlling manager or the controlling shareholder. Empirical results put in evidence that block-shareholders are afraid of the loss of control. Therefore, they collude with fixed-claim holders in order to share control premiums and to get in return additional debts in smoother conditions and lower rates. Other firms under their control may also enjoy these extra funds. The controlling shareholders are hence tempted to increase the firm leverage and by the way to increase their own private benefits. However, the manager is anxious to lose his empire building by increasing the firm debt. Thus, he is incited to decrease the firm leverage so as to maintain his private benefits already siphoned off.

These results highlight the importance that owners attach to control. But, this paper takes the analysis a step further by showing that the owner's fear of losing control can affect company characteristics such as capital structure. To some extent, agency conflicts among stakeholders help explain the various debt levels of French firms in practice. In fact, most French firms are family owned and the ownership is locked within the hands of few block-holders. Thus, the primary agency problem in such environment is not the failure of professional managers to satisfy the objectives of diffused shareholders, but rather the expropriation of minority shareholders by the controlling shareholders. This opportunistic behavior would deter outside investment and negatively affect the firm's value.

Likewise, our study suggests further investigating corporate governance and firm policies implications of concentrated ownership, depending on the levels of private benefits of control. For instance, it is worth analyzing the potential interactions between private benefits of control and other financial decisions such us equity issue and dividend policy. Another avenue for future research would be to compare the behavior of French firms with other EU countries' firms. But above all, this study has important implications for economic policy. The main implication is that it is important to differentiate between the demand and supply side constraints of finance. The government programs should be adapted to the firm's needs and characteristics. If firms prefer debts and do not want to raise equity capital, why to implement programs that help small companies to raise equity capital. Besides, French government is urged to enhance the legal protection of almost shareholders in order to escape any expropriation and appeal to foreign investors.

\section{References}

Baltagi, B.H. (1995). Econometric Analysis of Panel Data. John Wiley \& Sons.

Barclay, M., \& Holderness, C. (1989). Private Benefits from Control of Public Corporations. Journal of Financial Economics, 125, 371-395. http://dx.doi.org/10.1016/0304-405X(89)90088-3

Baums, T. (1993). Takeovers versus institutions in corporate governance in Germany. Contemporary Issues in Corporate Governance, Clarendon Press: Oxford.

Bebchuk, L. (1994). Efficient \& Inefficient Sales of Corporate Control. Quarterly Journal of Economics, 109, 957-994. http://dx.doi.org/10.2307/2118353

Bebchuk, L. (1999). A rent-protection theory of corporate ownership \& control. Working Paper 7203, National Bureau of Economic Research, Harvard University. 
Bennedsen, M., \& Wolfenzon, D. (2000). The balance of power in closely held corporations. Journal of Financial Economics, 58, 113-139. http://dx.doi.org/10.1016/S0304-405X(00)00068-4

Berger, P.G., Ofek, E., \& Yermack, D.L. (1997). Managerial entrenchment \& capital structure decisions. Journal of Finance, 52, 1411-1438. http://dx.doi.org/10.2307/2329441

Berkman, H., Cole, R.A., \& Fu, L.J. (2009). Expropriation through loan guarantees to related parties: Evidence from China. Journal of Banking \& Finance, 33, 141-156. http://dx.doi.org/10.1016/j.jbankfin.2007.11.001

Boubaker, S., \& Labégorre, F. (2008). Ownership structure, corporate governance \& analyst following: a study of French listed firms. Journal of Banking \& Finance, 32, 961-976. http://dx.doi.org/10.1016/j.jbankfin.2007.07.010

Bradley, M., Jarrell, G.A., \& Kim, E.H. (1984). On the existence of an optimal capital structure: theory \& finance. Journal of Finance, 39, 857-879. http://dx.doi.org/10.2307/2327950

Brailsford, T. J., Barry, O.L. \& Pua, S.L.H. (2002). On the relation between ownership structure \& capital structure. Accounting \& Finance, 42, 1-26. http://dx.doi.org/10.1111/1467-629X.00001

Cheung, Y.L., Jing, L., Lu, T., Rau, P.R., \& Stouraitis, A. (2009). Tunneling \& propping up: An analysis of related party transactions by Chinese listed companies. Pacific-Basin Finance Journal, 17, 372-393. http://dx.doi.org/10.1016/j.pacfin.2008.10.001

Claessens, S., Djankov, S., Fan, J., \& Lang, L. (2002). Disentangling the incentive \& entrenchment effects of large shareholdings. Journal of Finance, 57, 2741-2771. http://dx.doi.org/10.1111/1540-6261.00511

Claessens, S., Djankov, S., Fan, J., \& Lang, L. (1999). Expropriation of minority shareholders: Evidence from East Asia. Policy Research WP Series, 2088, World Bank, Washington, D.C.

Conover, T., \& Nichols, N. (2000). A further examination of income shifting through transfer pricing considering firm size \&/or distress. The International Journal of Accounting, 35, 189-211. http://dx.doi.org/10.1016/S0020-7063(00)00045-5

Dahya, J., Dimitrov, O., \& McConnell, J. (2008). Dominant shareholders, corporate boards, \& corporate value: A cross-country analysis. Journal of Financial Economics, 87, 73-100. http://dx.doi.org/10.1016/j.jfineco.2006.10.005

Demsetz H., \& Lehn K. (1985). The structure of corporate ownership: causes \& consequences. Journal of Finance, 50, 1029-1057.

Djankov, S., La Porta, R., Lopez-de-Silanes, F., \& Shleifer, A. (2008). The law \& economics of self-dealing. Journal of Financial Economics, 88, 430-465. http://dx.doi.org/10.1016/j.jfineco.2007.02.007

Doidge, C., Karolyi, G., Lins, K., Miller, D., \& Stulz, R. (2009). Private Benefits of Control, Ownership, \& the Cross-listing Decision. Journal of Finance, 64, 425-466. http://dx.doi.org/10.1111/j.1540-6261.2008.01438.x

Dyck, A., \& Zingales, L. (2004). Private benefits of control: An international comparison. Journal of Finance, 59, 537-600. http://dx.doi.org/10.1111/j.1540-6261.2004.00642.x

Ehrhards, O., \& Nowak, E. (2003). Private benefits \& minority shareholder expropriation: empirical evidence from IPOs of German family-owned firms. Working paper, Humboldt University.

Faccio, M., \& Lang, L.H.P. (2002). The Ultimate Ownership of Western European Corporations. Journal of Financial Economics, 65, 365-395. http://dx.doi.org/10.1016/S0304-405X(02)00146-0

Faccio, M., Lang, L.H.P., \& Young, L. (2010). Pyramiding vs leverage in corporate groups: International evidence. Journal of International Business Studies, 41, 88-104. http://dx.doi.org/10.1057/jibs.2009.33

Fama, E., \& French, K. (1992). The cross sections of expected stock returns. Journal of Finance, 47, 427-466. http://dx.doi.org/10.2307/2329112

Field L.C. \& Karpoff J.P. (2002). Takeover Defenses of IPO firms. Journal of Finance, 57, 1857-1889. http://dx.doi.org/10.1111/0022-1082.00482

Filatotchev, I., \& Miekiewicz, T. (2006). Private benefits of control \& debt financing. In T.M. Mickiewicz (eds). Corporate Governance \& Finance in Pol\& \& Russia.

Filatotchev, I., Kepelyushnikov, R., Dyomina, N., \& Aukusionek, S. (2001). The effects of ownership concentration on investment \& performance in privatised firms in Russia. Managerial \& Decision Economics, 22, 299-313. http://dx.doi.org/10.1002/mde.1008

Friend, I., \& Lang, H. (1988). An empirical test of the impact of managerial self-interest on corporate capital structure. Journal of Finance, 43, 271-281. http://dx.doi.org/10.2307/2328459 
Grossman S.J., \& Hart O.D. (1980). Takeover bids, the free-rider problem \& the theory of the corporation. Bell Journal of Economics, 11, 42-64. http://dx.doi.org/10.2307/3003400

Grossman, S.J., \& Hart, O.D. (1982). Corporate financial structure \& management incentives. Working paper, University of Chicago Press, Chicago, IL.

Harris, M., \& Raviv, A. (1988). Corporate control contests \& capital structure. Journal of Financial Economics, 20, 55- 86. http://dx.doi.org/10.1016/0304-405X(88)90040-2

Harris, M., \& Raviv, A. (1990). Capital structure \& the information role of debt. Journal of Finance, 45, 321-350. http://dx.doi.org/10.2307/2328660

Holderness, C.G. (2003). A survey of block-holders \& corporate control. Economic PolicyReview - Federal Reserve Bank of New York, April, 51-64.

Holl\&, J. (1994). Bank lending relationships \& the complex nature of bank-corporate relations. Journal of Business Finance \& Accounting, 21, 367-393. http://dx.doi.org/10.1111/j.1468-5957.1994.tb00325.x

Hwang J., \& Hu B. (2009). Private Benefits: Ownership versus Control. Journal of Financial Research, 32, 365-393. http://dx.doi.org/10.1111/j.1475-6803.2009.01254.x

Jensen, G., Solberg, D., \& Zorn, T. (1992). Simultaneous determination of insider ownership, debt, \& dividend policies. Journal of Financial \& Quantitative Analysis, 27, 247-263. http://dx.doi.org/10.2307/2331370

Jensen, M., \& Meckling, W. (1976). Theory of the firm: Managerial behaviour, agency costs \& ownership structure. Journal of Financial Economics, 3, 305-360. http://dx.doi.org/10.1016/0304-405X(76)90026-X

Jensen, M.C. (1986). Agency costs of free cash flow, corporate finance, \& takeover. American Economic Review, 76, 323-329.

Johnson, S., La Porta, R., Lopez-de-silanes, F., \& Shleifer, A. (2000). Tunneling. American Economic Review, 90, 22-27. http://dx.doi.org/10.1257/aer.90.2.22

Kang, J., \& Kim, J. (2006). Private benefits of control \& firm leverage: An analysis of Korean firms. Review of Quantitative Finance \& Accounting, 27, 439-463. http://dx.doi.org/10.1007/s11156-006-0046-z

Kraus, A., \& Litzenberger, R.H. (1973). A State-Preference Model of Optimal Financial Leverage. Journal of Finance, 28, 911-922. http://dx.doi.org/10.2307/2978343

La Porta, R., Lopez de Silanes, F., \& Shleifer, A. (1999). Corporate ownership around the world. Journal of Finance, 54, 471-517. http://dx.doi.org/10.1111/0022-1082.00115

La Porta, R., Lopez de Silanes, F., Shleifer, A., \& Vishny, R. (1998). Law \& finance. Journal of Political Economy, 106, 1113-1155. http://dx.doi.org/10.1086/250042

La Porta, R., Lopez-de-Silanes, F., Shleifer, A., \& Vishny, R. (2000). Investor protection \& corporate finance. Journal of Financial Economics, 58, 3-27. http://dx.doi.org/10.1016/S0304-405X(00)00065-9

Le Maux, J. (2004). Les déterminants de l'ampleur des bénéfices privés : un test sur données françaises. Finance Contrôle Stratégie, 7, 195-231.

Lease, R.C., McConnell, J.J., \& Mikkelson, W.H. (1983). The Market Value of Control in Publicly-Traded Corporations. Journal of Financial Economics, 11, 439-471. http://dx.doi.org/10.1016/0304-405X(83)90019-3

Maksimovic, V., \& Titman, S. (1991). Financial policy \& reputation for product quality. Review of Financial Studies, 4, 175-200. http://dx.doi.org/10.1093/rfs/4.1.175

Masulis, R., Wang, C. \& Xie, F. (2009). Agency Problems at Dual-Class Companies. Journal of Finance, 64, 1697-1728. http://dx.doi.org/10.1111/j.1540-6261.2009.01477.x

Mehran, H. (1992). Executive incentive plans, corporate control \& capital structure. Journal of Financial \& Quantitative Analysis, 27, 539-560. http://dx.doi.org/10.2307/2331139

Modigliani, F., \& Miller, M. (1958). The cost of capital, corporation finance \& the theory of investment. American Economic Review, 48, 261-297.

Modigliani, F., \& Miller, M. (1963). Corporate Income taxes \& the cost of capital: a correction. American Economic Review, 49, 261-297.

Modigliani, F., \& Perotti, E. (1997). Protection of minority interest \& the development of security markets. $\begin{array}{lllrl}\text { Managerial } \quad \text { Decision } & \text { Economics, } & 18, & 519-528 .\end{array}$ http://dx.doi.org/10.1002/(SICI)1099-1468(199711/12)18:7/8<519::AID-MDE857>3.0.CO;2-M 
Mueller, E. (2008). Benefits of control, capital structure \& company growth. Taylor \& Francis Journals, 40, 2721-2734.

Myers, S.C., \& Majluf, N.S. (1984). Corporate financing \& investment decisions when firms have information that investors do not have. Journal of Financial Economics, 20, 187-221. http://dx.doi.org/10.1016/0304-405X(84)90023-0

Myers, S.C. (1984). Capital structure puzzle. Journal of Finance, 39, 575-592. http://dx.doi.org/10.2307/2327916

Nenova, T. (2003). The Value of Corporate Votes \& control benefits: A cross-country analysis. Journal of Financial Economics, 68, 325-351. http://dx.doi.org/10.1016/S0304-405X(03)00069-2

Rajan, R., \& Zingales, L. (1995). What do we know about capital structure? Some evidence from international data. Journal of Finance, 50, 1421-1460. http://dx.doi.org/10.2307/2329322

Roosenboom, P., \& Schramade, W. (2006). The Price of Power: Valuing the Controlling Position of Owner-Managers in French IPO Firms. Journal of Corporate Finance, 12, 270-295. http://dx.doi.org/10.1016/j.jcorpfin.2005.02.001

Ross, S.A. (1977). The determination of financial structure, the incentive signaling approach. Bell Journal of Economics, 8, 23-40. http://dx.doi.org/10.2307/3003485

Shleifer, A., \& Vishny, R. (1997). A survey of corporate governance. Journal of Finance, 53, 737-784. http://dx.doi.org/10.2307/2329497

Stulz, R. (1988). Managerial control of voting rights: Financing policies \& the market for corporate control. Journal of Financial Economics, 20, 25-54. http://dx.doi.org/10.1016/0304-405X(88)90039-6

Stulz, R. (1990). Managerial discretion \& optimal financing policies. Journal of Financial Economics, 26, 3-28. http://dx.doi.org/10.1016/0304-405X(90)90011-N

Tai, B.Y., Liu, X., \& Liu, J.M. (2007). Related-party transactions, corporate performance, \& the effectiveness of corporate governance mechanism: evidence from the Chinese stock market. Journal of international business \& economics, 5, 117-131.

Titman, S., \& Wessels, R. (1988). The determinants of capital structure choice. Journal of Finance, 43, 1-19. http://dx.doi.org/10.2307/2328319

Weifeng, H., Zhaoguo, Z., \& Shasha, Z. (2008). Ownership structure \& the private benefits of control: an analysis of Chinese firms. Corporate Governance, 8, 286- 298. http://dx.doi.org/10.1108/14720700810879178

Wooldridge J.M. (2006). Introductory Econometrics: A Modern Approach, 3rd ed, OH: South-Western College Publishing, Cincinnati.

Zhang, Z., He, W., \& Chen, J. (2008). Firm leverage \& the private benefits of control in Chinese firms. Afro-Asian Journal of Finance \& Accounting, 1, 6-16. http://dx.doi.org/10.1504/AAJFA.2008.016887

Zingales, L. (1994). The value of the voting right: A survey of the Milan stock exchange experience. Review of Financial Studies, 7, 125-148. http://dx.doi.org/10.1093/rfs/7.1.125

Table 1. Descriptive Statistics

\begin{tabular}{|l|l|l|l|l|l|}
\hline Variables & Media & Mean & Min & Max & S.D \\
\hline CONC & 0.466 & 0.453 & 0.033 & 0.999 & 0.245 \\
\hline RPT & 7.760 & 6.471 & 0 & 11.244 & 3.699 \\
\hline Exc_comp & 6.419 & 6.402 & 4.141 & 8.636 & 0.9409 \\
\hline SIZE & 13.842 & 14.039 & 7.980 & 19.003 & 2.078 \\
\hline LEV & 0.5439 & 0.555 & 0.040 & 1.299 & 0.196 \\
\hline ROA & 0.067 & 0.067 & -0.285 & 0.599 & 0.093 \\
\hline TANG & 0.158 & 0.211 & 0.010 & 0.982 & 0.191 \\
\hline Growth & 2.039 & 0.180 & 45.275 & 3.619 \\
\hline $\begin{array}{l}\text { Variables: CONC (sum of the shares of the three major shareholders); RPT (neperian logarithm (1+the amount of related party transactions)); } \\
\text { Exc_comp (neperian logarithm of the spread between the management wage and the sector-based average); SIZE (neperian logarithm of book } \\
\text { value of the total assets of the firm), LEV (total debt over assets), ROA (ratio of profit before interest and tax to total assets); TANG (ratio of } \\
\text { tangible assets to total assets); Growth (market-to-book ratio). }\end{array}$
\end{tabular}


Table 2. Pairwise Correlations

\begin{tabular}{|c|c|c|c|c|c|c|c|c|}
\hline & LEV & RPT & Exc_comp & $\mathrm{CONC}$ & SIZE & Growth & TANG & ROA \\
\hline LEV & 1.000 & & & & & & & \\
\hline RPT & $\begin{array}{c}0.0948^{*} \\
(0.064)\end{array}$ & 1.000 & & & & & & \\
\hline Exc-comp & $\begin{array}{l}-0.0469 \\
(0.3648)\end{array}$ & $\begin{array}{l}-0.2208^{*} \\
(0.0001)\end{array}$ & 1.000 & & & & & \\
\hline CONC & $\begin{array}{c}0.0306 \\
(0.5029) \\
\end{array}$ & $0.1459 *(0.0045)$ & $\begin{array}{c}-0.3685^{*} \\
(0.000)\end{array}$ & 1.000 & & & & \\
\hline SIZE & $\begin{array}{c}0.050 \\
(0.235) \\
\end{array}$ & $\begin{array}{l}-0.232 * \\
(0.000) \\
\end{array}$ & $\begin{array}{l}0.726^{*} \\
(0.000) \\
\end{array}$ & $-0.2664 *(0.000)$ & 1.000 & & & \\
\hline Growth & $0.1766 *(0.0001)$ & $\begin{array}{c}0.0286 \\
(0.5878) \\
\end{array}$ & $\begin{array}{l}-0.105^{*} \\
(0.0487) \\
\end{array}$ & $\begin{array}{c}0.0087 \\
(0.8567) \\
\end{array}$ & $\begin{array}{c}-0.1810^{*} \\
(0.0001)\end{array}$ & 1.000 & & \\
\hline TANG & $\begin{array}{l}-0.1504 * \\
(0.0003) \\
\end{array}$ & $\begin{array}{l}-0.136^{*} \\
(0.0077) \\
\end{array}$ & $\begin{array}{l}0.1349 * \\
(0.0086) \\
\end{array}$ & $\begin{array}{l}-0.033 \\
(0.468) \\
\end{array}$ & $\begin{array}{c}0.2669^{*} \\
(0.000)\end{array}$ & $\begin{array}{l}-0.199 * \\
(0.000) \\
\end{array}$ & 1.000 & \\
\hline ROA & $\begin{array}{c}-0.1952^{*} \\
(0.000)\end{array}$ & $\begin{array}{c}0.0350 \\
(0.4965)\end{array}$ & $\begin{array}{c}0.0053 \\
(0.9179) \\
\end{array}$ & $\begin{array}{c}0.0214 \\
(0.6396)\end{array}$ & $\begin{array}{c}0.0889^{*} \\
(0.034)\end{array}$ & $\begin{array}{c}0.0249 \\
(0.5854)\end{array}$ & $\begin{array}{l}-0.077^{*} \\
(0.066)\end{array}$ & 1.000 \\
\hline \multicolumn{9}{|c|}{$\begin{array}{l}\text { Variables: CONC (sum of the shares of the three major shareholders); RPT (neperian logarithm (1+the amount of related party transactions)); } \\
\text { Exc_comp (neperian logarithm of the spread between the management wage and the sector-based average); SIZE (neperian logarithm of book value } \\
\text { of the total assets of the firm), LEV (total debt over assets), ROA (ratio of profit before interest and tax to total assets); TANG (ratio of fixed assets } \\
\text { to total assets); Growth (market-to-book ratio). * denote significance at } 10 \% \text { level. }\end{array}$} \\
\hline
\end{tabular}

Table 3. The impact of debt on private benefits of control

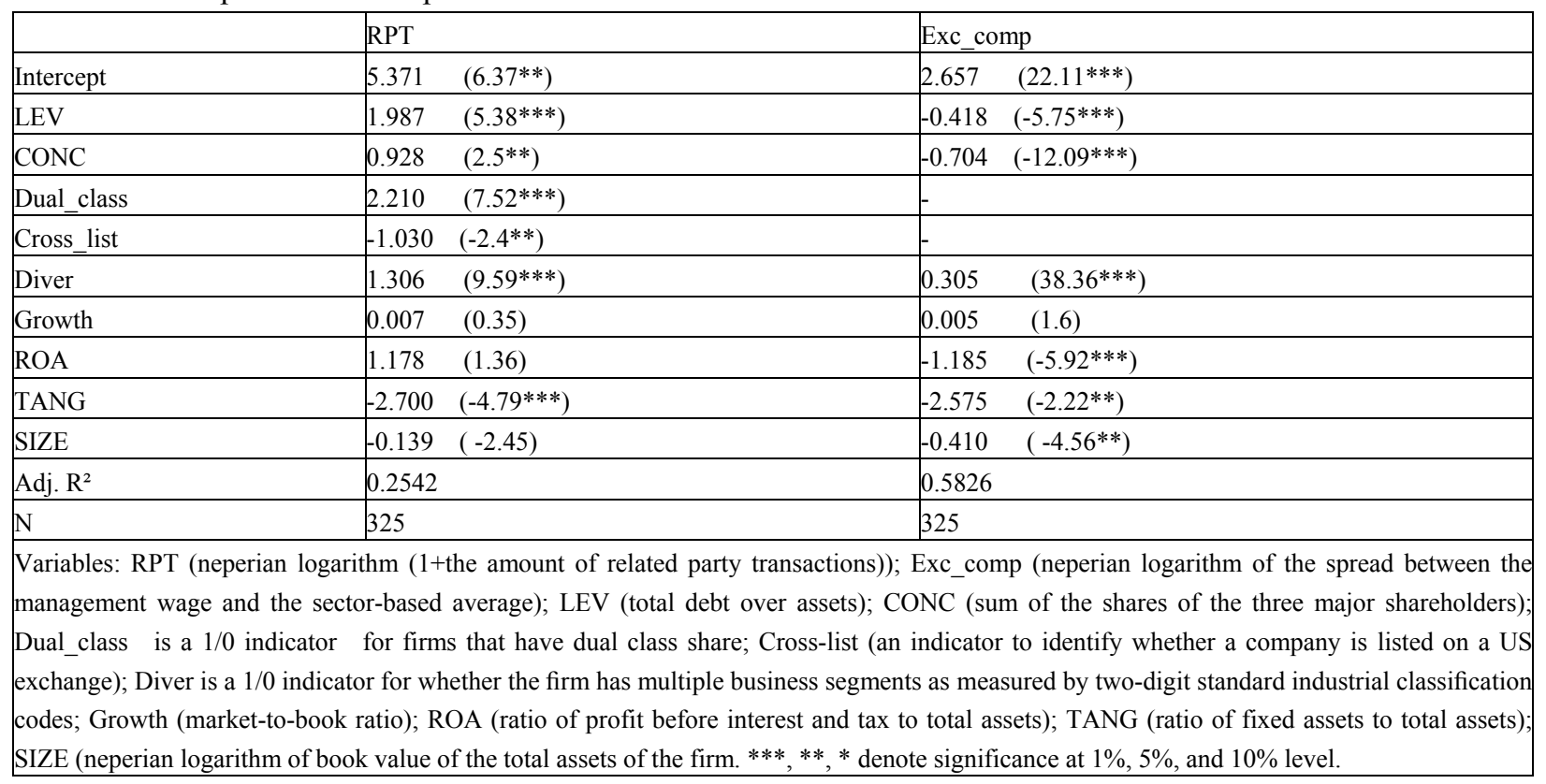


Table 4. The impact of the private benefits of control on leverage

\begin{tabular}{|c|c|c|c|c|c|c|c|c|c|}
\hline \multirow[b]{2}{*}{ Intercept } & \multicolumn{2}{|l|}{ (1) } & \multicolumn{3}{|r|}{ (2) } & \multicolumn{2}{|r|}{ (3) } & \multicolumn{2}{|r|}{ (4) } \\
\hline & 0.2811 & $(8.03 * * *)$ & & 0.2221 & $(4.77 * * *)$ & 0.511 & $(15.34 * * *)$ & 0.478 & $\left(8.68^{* * *}\right)$ \\
\hline RPT & 0.0068 & $(7.99 * * *)$ & & 0.0071 & $(8.14 * * *)$ & - & - & - & \\
\hline Exc_comp & & - & - & - & - & -0.0502 & $(-7.35 * * *)$ & -0.046 & $(-5.95 * * *)$ \\
\hline CONC & & - & - & 0.158 & $(2.64 * *)$ & - & - & -0.0004 & $(-0.01)$ \\
\hline $\mathrm{CONC}^{2}$ & & - & - & -0.1035 & $\left(-1.8^{*}\right)$ & - & - & 0.022 & $(0.31)$ \\
\hline SIZE & 0.021 & $\left(9.8^{* * *}\right)$ & & 0.022 & $(8.76 * * *)$ & 0.0313 & $\left(10.13^{* * *}\right)$ & 0.031 & $\left(8.3^{* * *}\right)$ \\
\hline TANG & -0.257 & $(-11.68 * * *)$ & & -0.239 & $\left(-16.12^{* * *}\right)$ & -0.277 & $(-13.91 * * *)$ & -0.2826 & $(-12.58 * * *)$ \\
\hline ROA & -0.552 & $(-7.49 * * *)$ & & -0.610 & $(-8.68 * * *)$ & -0.511 & $(-8.04 * *)$ & -0.578 & $(-3.58 * * *)$ \\
\hline Growth & 0.0082 & $(4.5 * * *)$ & & 0.0077 & $(4.39 * * *)$ & 0.0059 & $(3.55 * * *)$ & 0.0062 & $(-1.74 *)$ \\
\hline Adj. $\mathrm{R}^{2}$ & 0.1657 & & & 0.1703 & & 0.1246 & & 0.1155 & \\
\hline $\mathrm{N}$ & 356 & & & 356 & & 356 & & 356 & \\
\hline
\end{tabular}

Columns 1 and 2 exhibit the impact of related party transaction on the firm leverage while columns 3 and 4 present the impact of the CEO excessive compensation on debt. The influence of the stock-ownership is put in evidence in columns 2 and 4.

Variables: RPT (neperian logarithm (1+the amount of related party transactions)); Exc_comp (neperian logarithm of the spread between the management wage and the sector-based average); LEV (total debt over assets); CONC (sum of the shares of the three major shareholders); Growth (market-to-book ratio); ROA (ratio of profit before interest and tax to total assets); TANG (ratio of fixed assets to total assets); SIZE (neperian logarithm of book value of the total assets of the firm. $* * *, * *, *$ denote significance at $1 \%, 5 \%$, and $10 \%$ level.

Table 5. Simultaneous relationship between private benefits of control and leverage

\begin{tabular}{|c|c|c|c|c|}
\hline & \multicolumn{2}{|l|}{ (1) } & \multicolumn{2}{|l|}{ (2) } \\
\hline & LEV & RPT & LEV & Exc_comp \\
\hline Intercept & $0.151(1.26)$ & $4.920(2.59 * *)$ & $0.541\left(4.95^{* * *}\right)$ & $2.806 \quad\left(6.65^{* * *}\right)$ \\
\hline RPT & $0.0177(2.23 * *)$ & - & - & - \\
\hline Exc_comp & - & - & $-0.034(-1.94 *)$ & - \\
\hline LEV & - & $5.751(2.27 * *)$ & - & $-0.2802(-1.74 *)$ \\
\hline CONC & - & $1.095(1.53)$ & - & $-0.682\left(-3.45^{* * *}\right)$ \\
\hline Cross-list & - & $-1.203\left(-2.31^{* *}\right)$ & - & - \\
\hline Diver & - & $1.224(3.40 * * *)$ & - & - \\
\hline Dual_class & - & $1.909\left(4.36^{* * *}\right)$ & - & - \\
\hline Growth & $0.009\left(3.18^{* * *}\right)$ & $-0.0185(-0.33)$ & $0.0018(0.82)$ & $0.0019(0.31)$ \\
\hline $\mathrm{ROA}$ & $-0.561(-5.26 * * *)$ & - & $-0.382(-4.19 * * *)$ & $-0.3037(-1.13)$ \\
\hline TANG & $-0.263(-4.50 * * *)$ & - & $-0.251\left(-3.25^{* * *}\right)$ & $-0.3796(-1.43)$ \\
\hline SIZE & $0.024(4.07 * * *)$ & $-0.273(-2.31 * *)$ & $0.021\left(2.26^{* *}\right)$ & $0.294(10.69 * * *)$ \\
\hline Adj. $R^{2}$ & 0.1447 & 0.1673 & 0.1501 & 0.5737 \\
\hline $\mathrm{N}$ & 349 & 349 & 349 & 349 \\
\hline \multicolumn{5}{|c|}{$\begin{array}{l}\text { Variables: RPT (neperian logarithm (1+the amount of related party transactions)); Exc_comp (neperian logarithm of the spread between the } \\
\text { management wage and the sector-based average); LEV (total debt over assets); CONC (sum of the shares of the three major shareholders); } \\
\text { Dual_class is a } 1 / 0 \text { indicator for firms that have dual class share; Cross-list (an indicator to identify whether a company is listed on a US } \\
\text { exchange); Diver is a } 1 / 0 \text { indicator for whether the firm has multiple business segments as measured by two-digit standard industrial classification } \\
\text { codes; Growth (market-to-book ratio); ROA (ratio of profit before interest and tax to total assets); TANG (ratio of fixed assets to total assets); }\end{array}$} \\
\hline
\end{tabular}


Table 6. Sensitivity tests

\begin{tabular}{|c|c|c|c|c|c|c|c|c|c|c|}
\hline & \multicolumn{2}{|l|}{$(1)$} & \multicolumn{2}{|l|}{ (2) } & \multicolumn{2}{|l|}{ (3) } & \multicolumn{2}{|l|}{ (4) } & \multicolumn{2}{|l|}{ (5) } \\
\hline & LEV & RPT & LEV & RPT & LEV & RPT & LEV & RPT & LEV & RPT \\
\hline Intercept & $0.104(0.48)$ & $2.705(0.86)$ & $\begin{array}{l}-0.160 \\
(-0.09)\end{array}$ & $\begin{array}{l}2.280 \\
(0.58)\end{array}$ & $\begin{array}{l}-0.629 \\
(-0.85)\end{array}$ & $\begin{array}{l}4.930 \\
(1.3)\end{array}$ & $\begin{array}{l}-0.085 \\
(-0.24)\end{array}$ & $\begin{array}{l}5.865 \\
(1.67)\end{array}$ & $\begin{array}{l}0.093 \\
(0.26)\end{array}$ & $\begin{array}{l}-0.680 \\
(-0.12)\end{array}$ \\
\hline RPT & $0.028\left(1.93^{*}\right)$ & & $\begin{array}{l}0.010 \\
(1.02)\end{array}$ & & $\begin{array}{l}0.105 \\
(1.77 *)\end{array}$ & & $\begin{array}{l}0.046 \\
\left(1.78^{*}\right)\end{array}$ & & $\begin{array}{l}0.007 \\
(0.5)\end{array}$ & \\
\hline LEV & - & $1.086(2.38 * *)$ & & $\begin{array}{l}3.470 \\
(1.50)\end{array}$ & & $\begin{array}{l}2.540 \\
(1.94)\end{array}$ & & $\begin{array}{l}10.640 \\
(2.44)\end{array}$ & & $\begin{array}{l}2.084 \\
(1.37)\end{array}$ \\
\hline $\mathrm{CONC}$ & - & $\begin{array}{l}3.650 \\
(2.85 * * *)\end{array}$ & & $\begin{array}{l}1.960 \\
(1.25)\end{array}$ & & $\begin{array}{l}4.103 \\
(2.79) \\
\end{array}$ & & $\begin{array}{l}3.250 \\
(2.34)\end{array}$ & & $\begin{array}{l}0.589 \\
(0.22)\end{array}$ \\
\hline Cross_list & - & $\begin{array}{c}-0.802 \\
(-0.78)\end{array}$ & & $\begin{array}{l}-0.490 \\
(-0.5)\end{array}$ & & $\begin{array}{l}-2.000 \\
(-0.84)\end{array}$ & & $\begin{array}{l}0.157 \\
(0.08)\end{array}$ & & $\begin{array}{l}-0.220 \\
(-0.19)\end{array}$ \\
\hline Diver & - & $0.760(1.12)$ & - & $\begin{array}{l}1.470 \\
(1.79) \\
\end{array}$ & & $\begin{array}{l}0.587 \\
(0.54) \\
\end{array}$ & & $\begin{array}{l}0.548 \\
(0.66)\end{array}$ & & $\begin{array}{l}0.332 \\
(0.26) \\
\end{array}$ \\
\hline Dual_class & - & $\begin{array}{l}2.680 \\
(3.14 * * *)\end{array}$ & & $\begin{array}{l}2.920 \\
(3.35) \\
\end{array}$ & & $\begin{array}{l}2.700 \\
(3.13) \\
\end{array}$ & & $\begin{array}{l}3.940 \\
(3.25)\end{array}$ & & $\begin{array}{l}0.650 \\
(0.61) \\
\end{array}$ \\
\hline Growth & $\begin{array}{l}0.004 \\
(1.55) \\
\end{array}$ & $0.070(1.43)$ & $\begin{array}{l}0.024 \\
(3.63 * * *)\end{array}$ & $\begin{array}{l}0.119 \\
(0.71) \\
\end{array}$ & $\begin{array}{l}0.002 \\
(0.34) \\
\end{array}$ & $\begin{array}{l}0.026 \\
(0.73) \\
\end{array}$ & $\begin{array}{l}0.007 \\
(2.09 * *)\end{array}$ & $\begin{array}{l}0.036 \\
(0.8)\end{array}$ & $\begin{array}{l}0.007 \\
(0.07)\end{array}$ & $0.157(0.5)$ \\
\hline ROA & $\begin{array}{l}-0.346 \\
(-3.76 * * *)\end{array}$ & & $\begin{array}{l}-0.563 \\
(-3.43 * * *)\end{array}$ & & $\begin{array}{l}-0.411 \\
(-1.61) \\
\end{array}$ & & $\begin{array}{l}-0.180 \\
(-1.2)\end{array}$ & - & $\begin{array}{l}-0.756 \\
(-4.72 * * *)\end{array}$ & \\
\hline TANG & $\begin{array}{l}-0.209 \\
(-2.44 * *)\end{array}$ & & $\begin{array}{l}-0.140 \\
\left(-1.78^{*}\right) \\
\end{array}$ & & $\begin{array}{l}-0.715 \\
(-2.61 * *)\end{array}$ & & $\begin{array}{l}-0.308 \\
\left(-2.43^{* *}\right)\end{array}$ & & $\begin{array}{l}-0.15 \\
(-1.06) \\
\end{array}$ & \\
\hline SIZE & $0.022\left(2.08^{* *}\right)$ & $\left\{\begin{array}{l}-0.072 \\
(-0.38)\end{array}\right.$ & $\begin{array}{l}0.034 \\
\left(3.63^{* * *}\right)\end{array}$ & $\begin{array}{l}-0.140 \\
(-0.58)\end{array}$ & $0.040(1.39)$ & $\begin{array}{l}-0.060 \\
(-0.25)\end{array}$ & $\begin{array}{l}0.024 \\
(1.6)\end{array}$ & $\begin{array}{l}-0.083 \\
(-0.36)\end{array}$ & $\begin{array}{l}0.033 \\
(1.56)\end{array}$ & $\begin{array}{l}-0.204 \\
(-0.5)\end{array}$ \\
\hline $\operatorname{Adj} . \mathrm{R}^{2}$ & 0.115 & 0.158 & 0.220 & 0.362 & 0.233 & 0.127 & 0.089 & 0.489 & 0.103 & 0.034 \\
\hline $\mathrm{N}$ & 229 & 229 & 150 & 150 & 207 & 207 & 226 & 214 & 123 & 123 \\
\hline
\end{tabular}

(1): excluding widely held firms; (2): excluding family firms; (3): including only family firms; (4): controlling shareholder implicated in management; (5): controlling shareholder not implicated in management.

Variables: RPT (neperian logarithm (1+the amount of related party transactions)); LEV (total debt over assets); CONC (sum of the shares of the three major shareholders); Dual_class is a $1 / 0$ indicator for firms that have dual class share; Cross-list (an indicator to identify whether a company is listed on a US exchange); Diver is a $1 / 0$ indicator for whether the firm has multiple business segments as measured by two-digit standard industrial classification codes; Growth (market-to-book ratio); ROA (ratio of profit before interest and tax to total assets); TANG (ratio of fixed assets to total assets); SIZE (neperian logarithm of book value of the total assets of the firm. ***, **, * denote significance at $1 \%, 5 \%$, and $10 \%$ level. 